\title{
HUBUNGAN STATUS GIZI DENGAN KEJADIAN ANEMIA PADA KEHAMILAN TRIMESTER III DI POLINDES JABUNG
}

\author{
Siti Aisyah* \\ *Dosen Program Studi Diploma III Kebidanan Universitas Islam Lamongan \\ RINGKASAN
}

Kecukupan gizi sangat di butuhkan untuk setiap individu, sejak janin yang masih dalam kandungan bayi, anak, masa remaja,dewasa sampai usia lanjut. Kebutuhan gizi yang kurang pada ibu hamil dapat mengakibatkan terjadinya anemi pada ibu hamil berdasarkan survey awal di dapatkan 50\% dan 10 orang yang datang periksa ke polindes jabung mengalami anemia ringan. untuk mengatasi masalah tersebut diperlukan penanganan agar kehamilan berjalan dengan lancar. Tujuan penelitian ini adalah mengetahui hubungan status gizi dan kejadian pada trimester III.

Desain penelitian menggunakan analitik croseccional, metode sampling yang di gunakan adalah sampel random sampling . sampel yang di ambil sebanyak 28 responden yaitu ibu hamil. Variabel dalam penelitian ini adalah variabel independen dan dependen. Data penelitian ini di ambil dengan menggunakan lila (lingkar lengan atas, HB sahli dan lembar observasi. Setelah di tabulasi data yang dianalisa dengan menggunakan uji korelasi spirman dengan tingkat kemaknaan $\alpha$ : 0,05

Hasil penelitian menunjukan bahwa ibu hamil yang lila (lingkar lengan atas) kurang dari normal mengalami anemia sebanyak 10 responden dan yang tidak mengalami anemi sebanayk 1 responden sedangkan dari hasil pengujian statistic diperoleh hasil ada hubungan status gizi dengan kejadian anemia dimana nilai $\mathrm{P}=0,01$ dengan tingkat signifikan $0,01(\mathrm{P} \leq 0,05)$ dari hasil penelitian ini di dapatkan ada hubungan status dengan kejadian anemia.

Oleh karena itu hendaknya para ibu hamil agar meningkatkan status gizi yaitu mengkonsumsi makanan yang kaya akan zat besi dan teratur minum tablet fe.

Kata kunci : Status Gizi, Anemia

\section{PENDAHULUAN}

Dalam pokok program pembangunan kesehatan menuju Indonesia sehat 2020 disebutkan bahwa salah satunya terfokus pada kesehatan Ibu dan anak serta perbaikan gizi (Depkes RI, 2015). Sasaran yang menjadi prioritas utama adalah golongan rawan gizi seperti ibu hamil yang mengalami KEK
(Kurang Energi Kronis) dan Anemia gizi (Husaini, 2008).

$$
\text { Kecukupan gizi sangat }
$$
dibutuhkan oleh setiap individu, sejak janin yang masih dalam kandungan, bayi, anak-anak, masa remaja, dewasa sampai usia lanjut. kekurangan gizi dalam kehamilan akan menyebabkan kegagalan pertumbuhan fisik dan perkembangan kecerdasan, 
menurunkan produktifitas kerja dan menurunkan daya tahan tubuh, yang meningkatkan angka kesakitan dan kematian.

Ibu dan calon ibu merupakan kelompok rawan karena membutuhkan gizi yang cukup sehingga harus dijaga status gizi dan kesehatannya agar dapat melahirkan bayi yang sehat. Menyadari kondisi ekonomi masyarakat saat ini, kebutuhan zat gizi sulit sekali terpenuhi melalui konsumsi makanan yang kaya akan zat besi, karena umumnya bahan makanan ini harganya cukup mahal, mahalnya makanan kaya zat besi ini seakan tidak dapat dijangkau masyarakat yang berpenghasilan rendah atau miskin (Dep. Kes RI, 2015:1).

Pada kehamilan relative terjadi anemia karena darah ibu hamil mengalami hemodilusi, dengan peningkatan volume $30 \%$ sampai $40 \%$ yang puncaknya pada kehamilan 32 sampai 34 minggu. Jumlah peningkatan sel darah $18 \%$ sampai 30\% dan hemoglobin sekitar 19\%. Bila hemoglobin ibu sebelum hamil sekitar 11 gram\% maka dengan terjadinya hemodilusi akan mengakibatkan anemia hamil yaitu $\mathrm{Hb}$ ibu akan menjadi 9,5 sampai 10 gram\% (Manuaba, 2005:30).

Angka anemia kehamilan di Indonesia menunjukkan nilai yang cukup tinggi. Menurut WHO kejadian anemi ibu hamil berkisar antara $20 \%$ sampai $89 \%$ dengan menetapkan 11 gram sebagai dasarnya. Hoo Swie Tjiong menemukan angka anemia kehamilan $3,8 \%$ pada trimester I, $13,6 \%$ trimester II, dan $24,8 \%$ trimester III (Manuaba, 2005:29). Data SKRT tahun 2005 dan 2010 menyatakan prevalensi anemia pada ibu hamil adalah 50,9\% (Dep.Kes RI,
2012:1). Menurut Ikatan Bidan Indonesia (2015) untuk deteksi anemia pada kehamilan maka pemeriksaan kadar $\mathrm{Hb}$ ibu hamil harus dilakukan pada kunjungan pertama dan minggu ke 28 .

Pada survey awal yang dilakukan selama tiga hari pada tanggal 19 sampai 21 Januari 2016 di Polindes Jabung Kecamatan Laren Kabupaten Lamongan didapatkan dari 10 orang yang datang ke polindes untuk periksa hamil dan dilakukan pemeriksaan $\mathrm{HB}$ sahli didapatkan sebanyak 6 orang mengalami anemia yaitu $\mathrm{Hb}<10,9$ gram $\%$ dari 6 orang yang dinyatakan anemia 5 orang yang dinyatakan Lila $<23,5 \mathrm{~cm}$. Jadi masih tinggi kejadian anemia pada ibu hamil.

Faktor-faktor penyebab terjadinya anemia kurang gizi atau malnutrisi, kurang zat besi dalam diet, malabsorbsi, kehilangan darah yang banyak : persalinan yang lalu, haid, penyakit - penyakit kronis : TBC, paru, cacing usus, malaria dan lain - lain (Mochtar R, 2008 : 145 ), jarak kehamilan dan persalinan., wanita yang sering mengalami kehamilan dan melahirkan atau paritas, pendidikan dan tingkat sosial ekonomi yang rendah (Manuaba IBG, 2006 : 29).

Kebutuhan gizi yang kurang pada ibu hamil dapat mengakibatkan terjadinya anemi pada ibu hamil, abortus, partus prematurus, inersia uteri, perdarahan pasca persalinan, sepsis puerperalis dan sebagainya. Sedangkan kebutuhan gizi yang berlebihan juga dapat mengakibatkan komplikasi seperti kegemukan, pre eklamsi, janin besar dan sebagainya (Rustam, 1998:59). Anemi pada kehamilan merupakan masalah nasional karena mencerminkan nilai kesejahteraan sosial ekonomi 
masyarakat, dan pengaruhnya sangat besar terhadap kualitas sumber daya manusia (Manuaba, 2006:29).

Upaya untuk mencegah dan mengobati penyakit kekurangan darah (anemia) pada ibu hamil, maka setiap ibu hamil harus mengonsumsi makanan yang kaya akan zat besi, untuk meningkatkan status gizi, misalnya minum tablet $\mathrm{Fe}$,Vitamin $\mathrm{C}$, daging, ikan, hati dan sayuran yang berdaun hijau seperti bayam, kangkung dan daun papaya dan melakukan pemeriksaan sebelum hamil sehingga dapat diketahui datadata dasar kesehatan umum calon ibu tersebut.

Dalam pemeriksaan HB sahli kesehatan pada ibu hamil sebaiknya dilakukan juga pemeriksaan laboratorium, Bila kadar $\mathrm{Hb}$ kurang 11 gram $\%$ pada kehamilan dinyatakan termasuk anemia dan harus diberi suplement tablet besi yang berisi $60 \mathrm{mg}$ zat besi dan 0,5 $\mathrm{mg}$ asam folat, diminum secara teratur 1 tablet per hari selama 90 hari berturut-turut, bila kadar $\mathrm{Hb}$ masih kurang 11 gram\% pemberian tablet dilanjutkan. Tetapi pada kenyataanya masih tinggi angka kejadian anemia kehamilan di polindes Desa Jabung kecamatan Laren kabupaten Lamongan oleh karena itu peneliti ingin melakukan penelitian hubungan status gizi dengan kejadian anemia pada ibu hamil.

\section{TUJUAN PENELITIAN}

Mengetahui hubungan status gizi dengan kejadian anemia pada kehamilan di Polindes Desa Jabung Kecamatan Laren Kabupaten Lamongan.

\section{TINJAUAN PUSTAKA}

Gizi atau disebut juga nutrisi, merupakan ilmu yang mempelajari perihal makanan serta hubungannya dengan kesehatan (Paath, 2004:4). Gizi adalah suatu proses organisme menggunakan makanan yang dikonsumsi secara normal melalui proses digesti, absorpsi, transportasi, penyimpanan, metabolisme dan pengeluaran zat-zat yang tidak digunakan untuk mempertahankan kehidupan, pertumbuhan dan fungsi normal dari organ-organ, serta menghasilkan energi (Supariasa, 2002:17).

Kehamilan adalah suatu hal dalam kehidupan yang dapat membuat keluarga bahagia. Pada kehamilan terjadi perubahan fisik dan mental yang bersifat alami. Para calon ibu harus sehat dan mempunyai gizi cukup (berat badan normal) sebelum hamil dan setelah hamil. Harus mempunyai kebiasaan makan yang teratur dan bergizi, berolah raga teratur dan tidak merokok. Jika ibu tidak mendapat gizi yang cukup selama kehamilan, maka bayi yang dikandungnya akan menderita kekurangan gizi. Jadi meskipun sudah cukup bulan, bayi tersebut akan lahir dengan berat badan dibawah 2500 gram atau bayi berat lahir rendah (BBLR). Ibu yang menderita kekurangan gizi juga akan kekurangan ASI bila kelak menyusui (Paath, 2008:51). Salah satu persiapan yang dilakukan saat hamil adalah menjaga asupan nutrisi yang bagus untuk ibu dan bayi yang ada didalam kandungan, karena selama kehamilan janin didalam tubuh ibu berkembang dengan pesat. Perkembangan ini sangat dipengaruhi oleh kecukupan zat gizi ibu (Ninik Dwi A, 2008). 
Berat badan bayi baru lahir ditentukan oleh (disamping faktor genetik) status gizi janin. Status gizi janin ditentukan antara lain oleh status gizi ibu waktu melahirkan dan keadaan ini dipengaruhi pula oleh status gizi pada waktu konsepsi. Status gizi ibu sewaktu konsepsi dipengaruhi oleh Keadaan sosial dan ekonomi ibu sebelum hamil, Asupan gizi selama kehamilan, Jarak kelahiran jika yang dikandung bukan anak pertama, Paritas, Usia kehamilan pertama.

Status gizi ibu hamil pada waktu pembuahan dan selama hamil dapat mempengaruhi pertumbuhan janin yang sedang dikandung. Seorang ibu yang sedang hamil mengalami kenaikan berat badan sebanyak 10-12 kg. Pada trimester pertama kenaikan itu hanya kurang dari $1 \mathrm{~kg}$, trimester ke 2 kurang lebih $3 \mathrm{~kg}$, sedangkan trimester terakhir kira- kira $6 \mathrm{~kg}$. Kenaikan tersebut meliputi kenaikan komponen janin: pertumbuhan janin, plasenta, cairan amnion (Huliana 2001).

Berat badan ibu hamil harus memadai, bertambah sesuai umur kehamilan, berat badan yang bertambah normal akan menghasilkan anak yang normal. Kenaikan berat badan ideal ibu hamil $7 \mathrm{~kg}$ untuk ibu yang gemuk dan 12,5 $\mathrm{kg}$ untuk ibu yang tidak gemuk. Jika kurang dari normal beresiko keguguran, anak lahir premature, bayi berat lahir rendah, gangguan kekuatan rahim mengeluarkan anak dan perdarahan setelah persalinan (Paath, 2008:54). Salah satu parameter untuk mengetahui status gizi adalah dengan melihat peningkatan berat badan selama kehamilan atau pemeriksaan antropometri yang bisa dilakukan ialah penimbangan berat, pengukuran tinggi, penentuan berat ideal dan pola pertambahan berat. Berat pada kunjungan pertama ditimbang sementara berat sebelumnya jangan terlewat untuk ditanyakan. Berat sebelum hamil berguna untuk penentuan prognosis serta keputusan perlu tidaknya dilakukan terapi gizi secara intensif. Status gizi buruk ditandai oleh berat sebelum hamil $10 \%$ dibawah atau $20 \%$ diatas berat ideal (Arisman, 2004:10).

Anemi dalam kehamilan adalah kondisi ibu dengan kadar haemoglobin dibawah 11 gram\% pada trimester I dan 3 atau kadar $<10,5$ gram\% pada trimester II. Nilai batas tersebut dan perbedaannya dengan kondisi wanita tidak hamil terjadi karena hemodilusi pada trimester 2 (Sarwono, 2010:281). Anemia pada wanita tidak hamil didefinisikan sebagai konsentrasi hemoglobin yang kurang dari $12 \mathrm{~g} / \mathrm{dl}$ dan kurang dari $10 \mathrm{~g} / \mathrm{dl}$ selama kehamilan atau masa nifas. Konsentrasi hemoglobin lebih rendah pada pertengahan kehamilan, pada awal kehamilan dan kembali menjelang aterm, kadar haemoglobin pada sebagian besar wanita sehat yang memiliki cadangan besi adalah $11 \mathrm{~g} / \mathrm{dl}$ atau lebih. Atas alasan tersebut, Centers for disease control (1990) mendefinisikan anemia sebagai kadar haemoglobin kurang dari $11 \mathrm{~g} / \mathrm{dl}$ pada trimester pertama dan ketiga, dan kurang dari 10,5 g/dl pada trimester kedua (F. Gary Cunningham, 2011:1463).

\section{HIPOTESIS}

Terdapat hubungan status gizi dengan kejadian Anemia pada ibu hamil. 


\section{METODE PENELITIAN}

Peneliti menggunakan pendekatan adalah Cross Sectional, suatu penelitian dimana variabelvariabel yang termasuk faktor resiko dan variabel yang termasuk efek diobservasi sekaligus pada waktu yang sama (Soekidjo Notoatmodjo, 2005:145).

\section{HASIL PENELITIAN}

\section{Karateristik}

Reponden

\section{Berdasarkan Umur}

Tabel 1.1. Distribusi Responden berdasarkan umur di Polindes Desa Jabung Kecamatan Laren Kabupaten Lamongan pada bulan Juni 2016

\begin{tabular}{|l|l|l|}
\hline Usia & Jumlah & Presentase \\
\hline & 25 & $(89,3 \%)$ \\
& 3 & $(10,7 \%)$ \\
\hline Jumlah & 28 & $(100 \%)$ \\
\hline
\end{tabular}

Dari tabel 1.1 di atas diketahui hampir seluruh responden berumur 20-30 tahun yaitu $(89,3 \%)$ responden dan sebagian kecil berumur $31-40$ tahun yaitu $(10,7 \%)$ responden

\section{Karateristik}

Responden

\section{Berdasarkan Pendidikan}

Tabel 1.2 Distribusi responden berdasarkan pendidikan di Polindes Desa Jabung Kecamatan Laren Kabupaten Lamongan pada bulan Juni 2016

\begin{tabular}{|l|l|l|}
\hline Pendidikan & Jumlah & Presentase \\
\hline SD & 11 & $(39,3 \%)$ \\
SMP & 4 & $(14,3 \%)$ \\
SMA & 11 & $(39,9 \%)$ \\
$\begin{array}{l}\text { Perguruan } \\
\text { Tinggi }\end{array}$ & 2 & $(7,1 \%)$ \\
\hline Jumlah & 28 & $(100 \%)$ \\
\hline
\end{tabular}

Dari tabel di atas diketahui sebagian besar responden berpendidikan SMA yaitu $(39,9 \%)$ responden dan sebagian kecil Perguruan Tinggi (7,1 $\%$ ) responden

Karateristik

\section{Berdasarkan Pekerjaan}

Responden

Tabel 1.3 Distribusi responden berdasarkan pekerjaan di Polindes Desa Jabung Kecamatan Laren Kabupaten Lamongan pada bulan Juni 2016

\begin{tabular}{|l|l|l|}
\hline Pekerjaan & Jumlah & Presentase \\
\hline Pedagang & 8 & $(28,6 \%)$ \\
Guru & 8 & $(28,6 \%)$ \\
IRT & 12 & $(42,9 \%)$ \\
\hline Total & 28 & $(100 \%)$ \\
\hline
\end{tabular}

Dari tabel 1.3 di atas diketahui sebagian besar responden sebagai IRT yaitu $(42,9 \%)$ responden dan sebagian kecil sebagai Guru dan pedagang yaitu $(28,6 \%)$ responden

Karateristik responden berdasarkan lingkar lengan atas (Lila) pada ibu hamil

Tabel 1.4 Distribusi responden berdasarkan Linkar lengan atas (Lila) di Polindes Desa Desa Jabung Kecamatan Laren Kabupaten Lamongan pada bulan Juni 2016

\begin{tabular}{|l|l|l|}
\hline Lila & Jumlah & Presentase \\
\hline Kurang & 11 & $39,3 \%$ \\
Normal & 13 & $46,4 \%$ \\
Lebih & 4 & $14,3 \%$ \\
\hline Total & 28 & $100 \%$ \\
\hline
\end{tabular}

Dari tabel 1.4 di atas diketahui bahwa yang paling banyak yaitu Ibu memiliki Lila (Lingkar Lengan Atas) normal pada Ibu hamil berjumlah 13 responden $(46,6 \%)$ dan responden yang memiliki Lila lebih paling sedikit berjumlah $4 \quad(14,3 \%)$ responden.

Karateristik berdasarkan kejadian Anemia

Tabel 1.5 Distribusi responden berdasarkan kejadian Anemia di 
Polindes Desa Jabung Kecamatan Laren Kabupaten Lamongan pada bulan Juni 2016

\begin{tabular}{|l|l|l|}
\hline $\begin{array}{l}\text { Kejadian } \\
\text { Anemia }\end{array}$ & Jumlah & Presentase \\
\hline Berat & 9 & 32,1 \\
Sedang & 4 & 14,3 \\
Ringan & 4 & 14,3 \\
Baik & 11 & 39,3 \\
\hline Total & 28 & 100 \\
\hline
\end{tabular}

Dari tabel 1.5 di atas diketahui hampir seluruh besar responden keadaannya baik yaitu (39,3\%) responden dan sebagian kecil terjadi Anemia sedang dan ringan yaitu $(14,3 \%)$ responden.

Hubungan status gizi dengan kejadian anemia pada kehamilan

Tabel 1.6 Hubungan status gizi dengan kejadian anemia pada kehamilan di Polindes Desa Jabung Kecamatan Laren Kabupaten Lamongan pada bulan Juni 2016
Dari hasil statistik dipertegas dari uji korelasi Spearman $\left(\mathrm{r}_{\mathrm{s}}\right)$ dengan nilai kemaknaan $5 \%(0,05)$, temukan $\mathrm{p}=$ $0,01(\mathrm{p}<0,05)$ dan $\mathrm{r}_{\mathrm{s}}=0,460$

Dari hasil uji korelasi tersebut maka peneliti mengambil kesimpulan bahwa $\mathrm{H}_{0}$ ditolak, berarti ada hubungan antara status gizi dengan kejadian anemia pada kehamilan.

\section{PEMBAHASAN}

Berdasarkan tabel 1.1 dapat diketahui LILA (Lingkar Lengan Atas) selama hamil yang kurang sebanyak 17 responden (60.7\%) dan ibu hamil dengan LILA normal 11 responden $(39,9 \%)$. Dari data tersebut menunjukkan bahwa ibu yang hamil trimester III yang memiliki LILA selama hamil yang kurang lebih banyak dibandingkan dengan ibu hamil yang memiliki LILA normal, dari penelitian menunjukkan bahwa ibu hamil yang LILA nya kurang mengalami anemia berat sedangkan ibu hamil yang

\begin{tabular}{|lllllll|}
\hline \multirow{2}{*}{ No } & Lila $($ Lingkar & Anemia & & & \multirow{2}{*}{ Total } \\
\cline { 3 - 6 } & Lengan Atas) & Berat & Sedang & Ringan & Baik & \\
\hline 1. & Lebih & $7(63,6 \%)$ & $2(18,2 \%)$ & $1(9,1 \%)$ & $1(9,1 \%)$ & $11(100 \%)$ \\
2. & Normal & $1(7,7 \%)$ & $1(7,7 \%)$ & $2(15,4 \%)$ & $9(69,2 \%)$ & $13(100 \%)$ \\
3. & Kurang & $1(25,0 \%)$ & $1(25,0 \%)$ & $1(25,0 \%)$ & $1(25,0 \%)$ & $4(100 \%)$ \\
4. & Total & $9(32,1 \%)$ & $4(14,3 \%)$ & $4(14,3 \%)$ & $11(39,3 \%)$ & $28(100 \%)$ \\
\hline \multicolumn{5}{r}{} & rs $=0,460$ & \multicolumn{5}{c}{$\mathrm{P}=0,014$} \\
\hline
\end{tabular}

Dari tabel tabulasi pada tabel 1.6 menunjukkan bahwa dari 11 responden yang memiliki lingkar lengan atas kurang dari normal,sebagian besar mengalami Anemia pada kehamilan 10 responden $(90,9 \%), 13$ responden yang memiliki lingkar lengan atas normal,sebagian besar tidak mengalami anemia $9 \quad(69,2 \%)$ responden.Dan 4 responden yang memiliki lingkar lengan atas lebih rata-rata anemia berat $1(25,0 \%)$ responden.
Lilanya normal tidak mengalami anemia.

Kehamilan selalu berhubungan dengan perubahan fisiologis yang berakibat peningkatan volume cairan dan sel darah merah serta penurunan konsentrasi protein pengikat nutrisi dalam sirkulasi darah, begitu juga dengan penurunan nutrisi mikro. Pada kebanyakan negara berkembang, perubahan ini dapat diperburuk oleh kekurangan nutrisi dalam kehamilan yang berdampak pada defisiensi nutrisi mikro seperti anemia yang dapat 
berakibat fatal pada ibu hamil dan bayi baru lahir (Parra, B. E., L. M. Manjarres, et al. 2005). Pada kekurangan asupan mineral seng (zinc) dalam kehamilan misalnya, dapat berakibat gangguan signifikan pertumbuhan tulang. Pemberian asam folat tidak saja berguna untuk perkembangan otak sejak janin berwujud embrio, tetapi menjadi kunci penting pertumbuhan fungsi otak yang sehat selama kehamilan (Christiansen, M. and E. Garne 2005). Kasus-kasus gangguan penutupan jaringan saraf tulang belakang(spina bifida) dan kondisi dimana otak janin tidak dapat terbentuk normal(anencephaly) dapat dikurangi hingga $50 \%$ dan $85 \%$ jika ibu hamil mendapat asupan cukup asam folat sebelum dia hamil. Ibu hamil harus mendapatkan asupan vitamin yang cukup sebelum terjadinya kehamilan karena pembentukan otak janin dimulai pada minggu-mingu pertama kehamilan, justru pada saat sang ibu belum menyadari dirinya telah hamil (Obeid, R. and W. Herrmann 2005). Pada kasus-kasus dimana janin mengalami defisiensi asam folat, selsel jaringan utama (stem cells) akan cenderung membelah lebih lambat daripada pada janin yang dikandung ibu hamil dengan asupan asam folat yang cukup. Sehingga stem cells yang dibutuhkan untuk membentuk jaringan otak juga berkurang. Selain itu, sel-sel yang mati juga akan bertambah, jauh lebih besar daripada yang seharusnya(Santoso, M. I. and M. S. Rohman (2005).

Dampak kekurangan gizi selama hamil dapat menyebabkan bayi berat lahir rendah, terhambatnya pertumbuhan otak janin, bayi lahir dengan kurang darah(anemia), bayi mudah kena infeksi dan dapat mengakibatkan abortus. Status gizi pada ibu hamil dapat ditingkatkan dengan menganjurkan ibu hamil untuk mengkomsumsi makanan yang memenuhi zat-zat gizi.

Berdasarkan tabel 1.5 diketahui bahwa dari 28 ibu hamil trimester III yang diteliti terdapat 17 ibu hamil yang $\mathrm{Hb}$ nya kurang 11 gram\% dan 11 ibu hamil yang $\mathrm{Hb}$ nya 11 gram\% atau lebih. Dari data tersebut menunjukkan bahwa ibu yang hamil trimester III yang $\mathrm{Hb}$ kurang dari 11 gram\% lebih banyak dari ibu hamil yang $\mathrm{Hb}$ nya diatas atau sama dengan 11 gram \%.

Namun seharusnya ibu hamil trimester III tidak mengalami anemia, sebab anemia pada kehamilan dapat berpengaruh pada saat persalinan, masa nifas serta janin. yang bisa menyebabkan berbagai komplikasi diantaranya terjadi:

1. Pengaruh anemia terhadap kehamilan diantaranya: dapat terjadi abortus, Persalinan premature, hambatan tumbuh kembang janin dalam rahim, mudah terjadi infeksi, ancaman dekompensasi kordis atau $\mathrm{Hb}<6$ gr $\%$, mola hidatidosa, hiperemesis gravidarum, perdarahan antepartum, ketuban pecah dini atau KPD

2. Bahaya saat persalinan: Gangguan his-kekuatan mengejan, kala I dapat berlangsung lama dan terjadi partus terlantar, kala II berlangsung lama sehingga dapat melelahkan dan sering memerlukan tindakan operasi kebidanan, kala III dapat diikuti retensio plasenta, kala VI dapat terjadi perdarahan post partum sekunder dan atonia uteri.

3. Pada masa nifas: Terjadi subinvolusi uteri yang 
menimbulkan perdarahan post partum, memudahkan infeksi puerperium, pengeluaran ASI berkurang, dekompensasi kordis, mendadak setelah persalinan terjadi anemia, dan mudah terjadi infeksi mamae.

4. Bahaya terhadap janin. Sekalipun tampaknya janin mampu menyerap berbagai nutrisi dari ibunya, dengan adanya anemia kemampuan metabolisme tubuh akan berkurang sehingga pertumbuhan dan perkembangan janin dalam rahim akan terganggu. Akibat anemia pada janin antara lain adalah; Abortus, kematiam intrauteri, persalinan prematuritas tinggi, berat badan lahir rendah. Kelahiran dengan anemia, dapat terjadi cacat bawaan (Manuaba IBG, 2007 : 38-39)

Pada penelitian dari hasil tabulasi silang pada tabel 1.6 menunjukkan bahwa dari 11 responden yang memiliki LILA kurang dari normal selama hamil mengalami anemia pada kehamilan 10 responden $(90,9 \%)$ sedangkan 1 responden $(6,7 \%)$ tidak mengalami anemia pada kehamilan, 13 responden yang memiliki LILA normal selama hamil mengalami anemia pada kehamilan sebanyak 4 responden $(36,4 \%)$ dan 9 responden (69.2\%) yang tidak mengalami anemia pada kehamilan. Dan pada 4 responden $(14,3 \%)$ yang memiliki LILA hamil lebih dari normal tidak mengalami anemia pada kehamilan

Dokter Poerwo Soedarmo, seorang ahli gizi telah mencetuskan ide untuk makanan orang Indonesia dengan konsep "empat-sehat", yaitu nasi, sayur, lauk-pauk dan buah serta "lima sempurna", yaitu empat sehat yang ditambah segelas susu. Konsep ini sangat beralasan karena Idonesia Negara agraris, dikelilingi oleh laut yang luas dan beraneka ikannya dan ternak

Pada ibu hamil dan menyusui sudah tentu ditambah dengan sekitar $10-15 \%$ dari nilai gizi normal.

Pertambahan berat badan ideal ialah sekitar 12-16 kg setelah kehamilan berusia 20 minggu. Sebelum kehamilan berumur 20 minggu perempuan hamil masih sering mengalami emesis sampai hiperemesis gravidarum, sehingga intake atau output makanan tidak seimbang.

Pada status gizi yang kurang pada ibu hamil, "berat badan lahir rendah" akan meningkat sekitar 2,38 kali dibandingkan dengan kehamilan dengan gizi yang cukup baik. Oleh karena itu, gizi ibu hamil memegang peranan penting untuk dapat tumbuh kembang dengan baik serta IQ (Intelegen Quotion) yang relative tinggi. Disamping itu pelayanan antenatal yang dianjurkan dan dianggap sudah memenuhi kriteria ibu hamil cukup 4 kali selama hamil. Pada pemeriksaan antenatal jangan lupa lakukan pemeriksaan laboratorium dasar seperti pemeriksaan darah lengkap, urine lengkap dan gula darah. Berdasarkan pemeriksaan dasar tersebut dapat dikembangkan pemeriksaan lebih lanjut dengan indikasi tertentu. Angka anemia pada kehamilan di Indonesia cukup tinggi sekitar $67 \%$ dari semua ibu hamil dengan variasi tergantung pada daerah masingmasing. Sekitar 10-15\% tergolong anemia berat yang sudah tentu akan mempengaruhi tumbuh kembang janin dalam rahim.

Pada kenyataannya dalam penelitian yang telah dilakukan pada tanggal 10 sampai 20 Juli 2016 di 
Polindes Jabung Kecamatan Laren Kabupaten Lamongan, telah didapatkan dari 28 responden ibu hamil trimester III 17 ibu hamil dengan anemia yang memiliki LILA (Lingkar Lengan Atas) kurang dari normal, kejadian anemia tersebut dipengaruhi oleh beberapa faktor yang lain diantaranya umur, pendidkan, pekerjaan yang mempengaruhi keadaan status social ekonomi dalam keluarga dan paritas seseorang.

Hal ini dipertegas dari uji korelasi Spearman $\left(\mathrm{r}_{\mathrm{s}}\right)$ dengan nilai kemaknaan 5\%(0,05), temukan $\mathrm{p}=$ $0,01(\mathrm{p}<0,05)$ dan $\mathrm{r}_{\mathrm{s}}=0,460$. Dari hasil uji korelasi tersebut maka peneliti mengambil kesimpulan bahwa ada hubungan antara status gizi dengan kejadian anemia pada kehamilan.

\section{KESIMPULAN}

Sebagian besar ibu hamil yang datang periksa ke Polindes Desa Jabung Kecamatan Laren Kabupaten Lamongan mempunyai status gizi kurang

Hampir seluruhnya ibu hamil yang datang periksa ke Polindes Desa Jabung Kecamatan Laren Kabupaten Lamongan mengalami anemia berat.

Ada hubungan antara status gizi pada ibu hamil dengan kejadian anemia pada kehamilan trimester III di Polindes Desa Jabung Kecamatan Laren Kabupaten Lamongan

\section{SARAN}

Bagi masyarakat . Untuk masyarakat khususnya ibu hamil agar mengkonsumsi makanan kaya akan zat besi.

Bagi tenaga kesehatan. Bagi tenaga kesehatan terutama bidan diharapkan mampu melakukan KIE tentang pentingnya zat besi dalam kehamilan shingga dapat mengurangi kejadian anemia pada kehamilan

Bagi Peneliti Selanjutnya. Hendaknya penelitian ini dapat dijadikan data awal penelitian, untuk dapat dikembangkan lebih luas dan mengambil sampel lebih banyak sehingga hasilnya lebih reprensentatif.

\section{DAFTAR PUSTAKA}

Arisman. (2004). Gizi Dalam Daur Kehidupan. Jakarta : EGC.

Depkes. (2015). Program Penanggulangan ANEMIA GIZI PADA WANITA USIA SUBUR (WUS). Jakarta : Depkes RI.

Dewa Nyoman dkk. (2000). Penelitian Status Gizi. Jakarta : EGC.

IBG Manuaba, (2005). Ilmu Kebidanan, Penyakit Kandungan Dan Keluarga Berencana Untuk Pendidikan Bidan, Jakarta : EGC.

Ninik, Dwi A (2008). Anemia (http://www.blogdokter.net/2 008/06/17/anemia/)

Muchtar, Rustam. (2008). Sinopsis Obstetri. Jakarta : EGC.

Obeid, R. and W. Herman. (2005). Pelayanan Mempersiapkan Kehamilan dan Kelahiran. Yogyakarta : Pustaka Pelajar.

Paath, erna francin. (2008). Gizi dalam Kesehatan Reproduksi, Jakarta : EGC. 
Sarwono. (2010). Buku acuan nasional PELAYANAN KESEHATAN MATERNAL NEONATAL, Jakarta : YBPSP.

Suharsimi Arikunto, (2002). Prosedur Penelitian Suatu
Pendekatan Praktis. Jakarta :

PT. Rineka Cipta. 